\title{
PRODUCTIVITY OF COMMON OSIER (SALIX VIMINALIS L.) PLANTATIONS IN ARENOSOLS AND HISTOSOLS - MARGINAL CASE STUDY IN LITHUANIA
}

\begin{abstract}
Jūratė ALEINIKOVIENE், Institute of Agroecosystems and Soil Science, Faculty of Agronomy, Aleksandras Stulginskis University, Studentu g. 11, LT-53361, Akademija, Kauno raj., Lithuania, jurate.aleinikoviene@ asu.lt Vytautas Š́AUKŠČIUS, Institute of Forest Management and Wood Science, Faculty of Forest Sciences and Ecology, Faculty of Agronomy, Aleksandras Stulginskis University, Studentų g. 11, LT-53361, Akademija, Kauno raj., Lithuania, vytautas0509@gmail.com Gintautas ČINGA, Institute of Forest Management and Wood Science, Faculty of Forest Sciences and Ecology, Faculty of Agronomy, Aleksandras Stulginskis University, Studentų g. 11, LT-53361, Akademija, Kauno raj., Lithuania, gintautas.cinga@ asu.lt Romutė MIKUČIONIENE், Institute of Agroecosystems and Soil Science, Faculty of Agronomy, Faculty of Agronomy, Aleksandras Stulginskis University, Studentu g. 11, LT-53361, Akademija, Kauno raj., Lithuania, romute.mikucioniene@asu.lt Rimantas VAISVALAVIČIUS, Institute of Agroecosystems and Soil Science, Faculty of Agronomy, Faculty of Agronomy, Aleksandras Stulginskis University, Studentų g. 11, LT-53361, Akademija, Kauno raj., Lithuania, rimantas.vaisvalavicius@asu.lt

Productivity of two common osier (Salix viminalis L.) plantations in two different regions of Lithuania was marginally studied in 2014. The regions where the studies on common osier plantations have been done differed in soil groups. For that, the main importance of the study was to identify soil group typological parameters as well as to describe soil chemical characteristics. Further, it was important to estimate the volume of common osier biomass and to assess the impact of different soil parameters on osier biomass productivity. The obtained results let to exclude the importance of soil group as well as of soil typological unit on the productivity of common osier plantations in different regions. Thus, it was found that soil density is the main factor influencing the growth of common osier and it was optimal in studied Histosol (in South West of Lithuania). However, organic carbon and total nitrogen concentrations were the main parameters having impact on common osier productivity in Arenosols (in Western Lithuania).
\end{abstract}

Keywords: common osier, mobile $\mathrm{P}_{2} \mathrm{O}_{5}$ and $\mathrm{K}_{2} \mathrm{O}$, organic carbon, productivity of plantations, soil density, soil group, soil pH, total nitrogen.

\section{INTRODUCTION}

By 2020, the renewable energy consumption in Lithuania should reach up to 23 percent from the total energy use, that encourages the country to promote the most efficient and environmental friendly energetic technologies. It was foreseen and approved with following the targeted competences of renewable energy production in the order of the European Union (LR - Low of renewable energy resources, 2011). The renewable energy consumption in countries still is not sufficient, even though since 2009 it was assumed, that even fast-growing energy plants can reliably ensure the energy security, rural development and greenhouse gas emission reduction (FAO, 2011). Along with other fast-growing energy crops, the common osier (Salix viminalis L.) tree plantations are also perspective in completion of the renewable energy strategies. It either benefits in many ecological services and roles in soil-conservation, soil-protection and phytoremediation (Gradeckas et al., 2000; Noronha-Sannervik et al., 2006; Kuzovkina, Volk, 2009).

The expansion of fast-growing tree plantations mainly may occur in areas unsuitable for agriculture or in abandoned former arable land. Thus, fast growing willows (Salix spp.) and poplars (Populus spp.) are common tree species that naturally occupy agricultural lands which are left out of the use. On the other hand, the productive and rapid growth of energetic trees is only possible in fertile and well irrigated soils (Wael, 2009; Nassio et al., 2010). The common osier (Salix viminalis L.) grows with high water demands for producing high biomass with intensively transpired leaf areas (Hall, 2003). Although, even requirements for moisture content are considerable for all willows, the average precipitation in common osier plantations may be lower and range from 550 to $700 \mathrm{~mm}$ per year (Jasinskas, Liubarskis, 2003). Thus, the growth of common osier depends on ground water level. It is essential that ground water level in common osier plantations appear no deeper than in $1.5 \mathrm{~m}$ (Lygis et al., 2006; Linderson et al., 2007; Bastienė, Kirstukas, 2010). Also, the soil density is either the main parameter influencing the productivity of common osier plantations. It was

Copyright (C) 2015 The Authors. Published by Aleksandras Stulginskis University. This is an open-access article distributed under the terms of the Creative Commons Attribution License (CC-BY 4.0), which permits unrestricted use, distribution, and reproduction in any medium, provided the original author and source are credited. 
estimated, that in hardly compacted soils the development of osier plant roots is slower. Then, roots are hardly distributing even in the main root zone of $0-50 \mathrm{~cm}$ soil layer, thus, the above ground biomass production is either slower developing.

There is a lack in information on what are the limiting nutrient concentrations in soil for develop the productive common osier plantations, as still there is a statement following that common osier plantations as well as other energetic trees may grow in broad range conditions. However, it is obvious that only in fertile soils there are the optimal conditions for the cultivation of productive common osier plantations (Keoleian, Volk, 2005; Hangs et al., 2014). The aim of this marginal case study was to determine the 3 -year-old commercially cultivated common osier (Salix viminalis L.) biomass volume dependence on soil physical and chemical parameters. As the profitability of common osier is expressed by biomass production in extent growth area, the main objective was to estimate the main factors to influence the common osier plantation productivities in different soil groups (Arenosols and Histosols).

\section{RESEARCH METHODS}

The study was carried out in 2014 in two 3-year-old common osier (Salix viminalis L.) plantations, established for commercial purposes in two different regions of Lithuania. First studied in common osier plantation (Site I) of 10.1 ha was located in South West of Lithuania, at $55^{\circ} 8^{\prime} \mathrm{N}$ and $25^{\circ} 40^{\prime} \mathrm{E}$ (Patilčiai, Vilkaviškis district); second (Site II) - of 11.2 ha occurred in Western part of Lithuania, at 54 $39^{\prime} \mathrm{N}$ and $23^{\circ} 2^{\prime} \mathrm{E}$ (Kanteriškès, Šilutè district). Mean annual rainfall in these areas ranges from $543 \mathrm{~mm}$ to $620 \mathrm{~mm}$, the mean temperature in July is $17.2^{\circ} \mathrm{C}$ and in January $--4.9^{\circ} \mathrm{C}$. The vegetation period of common osier usually lasts more than 160 days from the middle of April to October. Soils before the installation of common osier plantations in sites were used as perennial grassland and no additional fertilizers have been applied.

According to the qualitative common osier growth parameters (visual observation of aboveground biomass increment/decline), two habitats have been set out in each site: (a) fertile (visible increase in aboveground biomass in comparison with unfertile site), and (b) unfertile (aboveground biomass is visible lower in comparison with fertile site). For the identification of differences in soils of common osier plantations, soil shallow pits (of $1.2 \mathrm{~m}$ in depth) have been mined in characteristic locality in both sites in fertile and in unfertile habitats (four soil pits in total). In each soil pit genetic horizons have been identified and soil group (according to the WRB, 2014), forest sites (according to Lithuanian forest site units) have been determined.

Soil sampling was carried out in September 2014. Soil samples were collected from every soil profile genetic horizon. In addition, soil samples for determination of mineral soil bulk density were taken with metallic cylinders (volume $78.5 \mathrm{~cm}^{3}$ ), fine soil fraction $\left(<2 \mathrm{~mm}\right.$ ) have been weighted after samples drying at $105{ }^{\circ} \mathrm{C}$. For chemical analysis of organic and mineral soil, samples were dried in laboratory at $40 \pm 2{ }^{\circ} \mathrm{C}$. Mineral soil samples were sieved through a $2 \mathrm{x}$ $2 \mathrm{~mm}$ sieve. In all samples, organic carbon (C) concentration was determined with a Heraeus apparatus (ISO 10694, dry combustion at $900{ }^{\circ} \mathrm{C}$ ), and total nitrogen (N) was analyzed using the Kjeldahl method (ISO 11261). Mobile potassium $\left(\mathrm{K}_{2} \mathrm{O}\right)$ and mobile phosphorus $\left(\mathrm{P}_{2} \mathrm{O}_{5}\right)$ was determined by the Egner-Riehm-Domingo (A-L) method (Egner et al., 1960); $\mathrm{pH}$ was potentiometrically measured in a $0.01 \mathrm{M} \mathrm{CaCl}_{2}$ suspension (ISO 10390). Soil chemical analyses have been done in the Agrochemical research laboratory (Lithuanian research centre for agriculture and forestry).

Common osier biomass production in 3-year-old plantations was measured in 2014 in the end of osier vegetation in beforehand installed survey plots (survey plots in width (a) consisted of two common osier shrubs in row, and in length (b) of twenty common osier shrubs in row) by cutting the shoots of selected diameter at the base. Before that, the diameter of all growing alive shoots was measured in the height of $1.3 \mathrm{~m}$. The thickest and the thinnest common osier have been identified in each sample plot. The combined fresh weight of the shoots on each cutting was then determined in the field to an accuracy of $0.5 \mathrm{~g}$. The dry matter content of each cut plant was determined in the laboratory by drying a separate fresh sample from each at $105^{\circ} \mathrm{C}$ for 2 days. The biomass production was calculated by regression based on measurements of the lengths and basal diameters (at $1.3 \mathrm{~m}$ in height) of shoots on all the stools of each shrub and determination of the correlation of shoot length and diameter with shoot dry weight from sample shoots (Directive of the European..., 2008; Stolarski et al., 2008; Röhle, Skibbe, 2012).

\section{RESULTS AND DISCUSSION}

Soil group identification in the study sites. Soil in the study sites have not been classified before the settlement of common osier plantations. Thus, soil genetic characteristics as well as supplement of plant nutrients have relayed on the formerly land use history (soil were used as perennial grassland and no additional fertilization have been performed). However, in 2014 the common osier plantations were three years old. That even could be concluded, that there were no sufficient impact of common osier plantations on soil development over the 3 years period.

Aboveground biomass in common osier plantations visually differed in the same study sites. For that, visual observation of common osier aboveground biomass extension / shortness let to presume that soil properties in studied sites could be the main factor affecting the growth intensity of osier plantations. Following that, in Site I (located in South West of Lithuania) and in Site II (located in Western part of Lithuania) two habitats have been set out: (a) fertile (visible increase in aboveground biomass in comparison with unfertile site), and (b) unfertile (aboveground biomass is visible lower in comparison with fertile site).

Taking into the account the genetic horizons (Table 1-4) identified in the pits, it was indicated that soil in fertile common osier habitat in Site I could be prescribed as Histosol. The Histosol were with well decomposed organic material in histic horizon (0-95 cm in depth) and could be prescribed for bog-histic drained fertile forest site typology group (Pcn, 
according Lithuanian classification). Soil in unfertile common osier habitat in Site I was prescribed as Arenosol with temporarily over moisture humidity unfertile forest site typology group $(L b)$. However, soils in Site II in fertile and unfertile habitats were prescribed as Arenosols but with different forest site typology groups, respectively, temporarily over moisture humidity fertile $(L c)$ and temporarily over moisture humidity unfertile $(L b)$ forest sites.

Estimated differences in soil groups as well as in forest sites confirmed that selection of study sites were reliable for comparative evaluation of common osier aboveground biomass productivity.

Soil density. The most proper soil density for plants to grow is $0.8-1.2 \mathrm{~g} \mathrm{~cm}^{-3}$. Meanwhile, the estimated density in common osier plantations of all three mineral soils was higher than optimal and ranged from $1.36 \mathrm{~g} \mathrm{~cm}^{-3}$ to $1.94 \mathrm{~g} \mathrm{~cm}^{-3}$ (Table 1-4).

Thus, the density of organic horizons in Histosol was lower than those of mineral soil horizons (Table 1-4). Although, the density of the histic horizons were differed between the horizons but was in average of $0.52 \mathrm{~g} \mathrm{~cm}^{-3}$. It could be indicated, that in studied Histosol the density was optimal for growth of common osier. There is an evidence, that the productivity of common osier is higher in soils even with increased soil density but the ground water level decline is mainly significantly effecting the increase in productivity of aboveground biomass in plantations (Phillips et al. 2014). On the other hand, common osier itself while intensively rooting over the growing period may either affect the soil compaction (Basher et al., 2008). The mentioned biological characteristics let to indicate the common osier as a plant suitable to prevent soil from erosion (Douglas et al., 2006).

Table 1. Main chemical parameters of Histosol in study site with fertile habitat in South West of Lithuania

\begin{tabular}{|c|c|c|c|c|c|c|}
\hline \multirow{2}{*}{$\begin{array}{c}\text { Horizon and } \\
\text { sampling depth, cm }\end{array}$} & \multirow{2}{*}{$\begin{array}{c}\text { Soil density, } \\
\mathrm{g} \mathrm{cm}^{-3}\end{array}$} & $\begin{array}{c}\text { Main chemical parameters } \\
\mathrm{g} \mathrm{kg}^{-1}\end{array}$ & $\begin{array}{c}\text { total N, } \\
\mathrm{g} \mathrm{kg}^{-1}\end{array}$ & $\begin{array}{c}\text { mobile } \mathrm{P}_{2} \mathrm{O}_{5}, \\
\mathrm{mg} \mathrm{kg}^{-1}\end{array}$ & $\begin{array}{c}\text { mobile } \mathrm{K}_{2} \mathrm{O}, \\
\mathrm{mg} \mathrm{kg}^{-1}\end{array}$ & $\mathrm{pH}_{\mathrm{CaCl} 2}$ \\
\hline $\mathrm{H}_{1} / 0-20$ & 0.36 & 468.6 & 29.3 & 143.3 & 231.0 & 6.01 \\
\hline $\mathrm{H}_{2} / 20-34$ & 0.59 & 422.3 & 23.8 & 120.2 & 200.3 & 5.83 \\
\hline $\mathrm{H}_{3} / 34-50$ & 0.64 & 440.5 & 24.2 & 135.8 & 208.5 & 5.93 \\
\hline $\mathrm{H}_{4} / 50-59$ & 0.64 & 460.1 & 26.0 & 118.0 & 103.2 & 5.89 \\
\hline $\mathrm{H}_{5} / 59-75$ & 0.44 & 451.0 & 25.3 & 131.2 & 112.5 & 6.05 \\
\hline $\mathrm{H}_{6} / 75-95$ & 0.46 & 466.8 & 26.4 & 126.4 & 80.3 & 5.93 \\
\hline $2 \mathrm{Cr} / 95-120$ & 1.33 & 183.4 & 0.43 & 10.8 & 97.1 & 5.40 \\
\hline
\end{tabular}

Table 2. Main chemical parameters of Arenosol in study site with unfertile habitat in South West of Lithuania

\begin{tabular}{|c|c|c|c|c|c|c|}
\hline \multirow{2}{*}{$\begin{array}{c}\text { Horizon and } \\
\text { sampling depth, cm }\end{array}$} & \multirow[b]{2}{*}{$\begin{array}{l}\text { Soil density, } \\
\qquad \mathrm{g} \mathrm{cm}^{-3}\end{array}$} & \multicolumn{5}{|c|}{ Main chemical parameters } \\
\hline & & $\begin{array}{c}\text { organic carbon, } \mathrm{g} \\
\mathrm{kg}^{-1}\end{array}$ & $\begin{array}{c}\text { total } \mathrm{N}, \\
\mathrm{g} \mathrm{kg}^{-1}\end{array}$ & $\begin{array}{c}\text { mobile } \mathrm{P}_{2} \mathrm{O}_{5}, \mathrm{mg} \\
\mathrm{kg}^{-1}\end{array}$ & $\begin{array}{c}\text { mobile } \mathrm{K}_{2} \mathrm{O}, \mathrm{mg} \\
\mathrm{kg}^{-1}\end{array}$ & $\mathrm{pHCaCl2}$ \\
\hline $\mathrm{AE} / 0-30$ & 1.66 & 4.8 & 0.8 & 143.8 & 135.3 & 5.33 \\
\hline B1s / 30-70 & 1.94 & 4.0 & 0.7 & 112.5 & 128.4 & 5.21 \\
\hline B2s / 70-80 & 1.81 & 3.6 & 0.3 & 100.1 & 99.7 & 4.80 \\
\hline B3sg / 80-97 & 1.59 & 3.8 & 0.3 & 93.3 & 90.2 & 4.93 \\
\hline $\mathrm{Cg} / 97-120$ & 1.52 & 3.2 & 0.4 & 79.0 & 83.6 & 4.54 \\
\hline
\end{tabular}

Table 3. Main chemical parameters of Arenosol in study site with fertile habitat in Western Lithuania

\begin{tabular}{|c|c|c|c|c|c|c|}
\hline \multirow[b]{2}{*}{$\begin{array}{c}\text { Horizon and } \\
\text { sampling depth, cm }\end{array}$} & \multirow[b]{2}{*}{$\begin{array}{l}\text { Soil density, } \\
\mathrm{g} \mathrm{cm}^{-3}\end{array}$} & \multicolumn{5}{|c|}{ Main chemical parameters } \\
\hline & & $\begin{array}{c}\text { organic carbon, } \mathrm{g} \\
\mathrm{kg}^{-1}\end{array}$ & $\begin{array}{l}\text { total N, } \\
\mathrm{g} \mathrm{kg}^{-1}\end{array}$ & $\begin{array}{c}\text { mobile } \mathrm{P}_{2} \mathrm{O}_{5}, \mathrm{mg} \\
\mathrm{kg}^{-1}\end{array}$ & $\begin{array}{c}\text { mobile } \mathrm{K}_{2} \mathrm{O}, \\
\mathrm{mg} \mathrm{kg}^{-1}\end{array}$ & $\mathrm{pH}_{\mathrm{CaCl}}$ \\
\hline $\mathrm{A} / 0-49$ & 1.36 & 12.8 & 2.7 & 195.6 & 138.8 & 6.33 \\
\hline $\mathrm{AE} / 49-64$ & 1.45 & 9.5 & 1.8 & 171.3 & 131.5 & 6.01 \\
\hline B1s / 64-81 & 1.48 & 5.2 & 0.7 & 112.1 & 100.3 & 5.44 \\
\hline B2 / 81-106 & 1.73 & 5.0 & 0.9 & 110.0 & 100.8 & 5.01 \\
\hline $\mathrm{Cg} / 106-120$ & 1.78 & 4.3 & 0.5 & 99.6 & 94.3 & 4.96 \\
\hline
\end{tabular}

Table 4. Main chemical parameters of Arenosol in study site with unfertile habitat in Western Lithuania

\begin{tabular}{|c|c|c|c|c|c|c|}
\hline \multirow{2}{*}{$\begin{array}{c}\text { Horizon and } \\
\text { sampling depth, cm }\end{array}$} & \multirow{2}{*}{$\begin{array}{l}\text { Soil density, } \\
\qquad \mathrm{g} \mathrm{cm}^{-3}\end{array}$} & \multicolumn{5}{|c|}{ Main chemical parameters } \\
\hline & & $\begin{array}{l}\text { organic carbon, } \mathrm{g} \\
\mathrm{kg}^{-1}\end{array}$ & $\begin{array}{l}\text { total } \mathrm{N} \\
\mathrm{g} \mathrm{kg}^{-1}\end{array}$ & $\underset{\mathrm{kg}^{-1}}{\text { mobile } \mathrm{P}_{2} \mathrm{O}_{5}, \mathrm{mg}}$ & $\begin{array}{l}\text { mobile } \mathrm{K}_{2} \mathrm{O}, \mathrm{mg} \\
\mathrm{kg}^{-1}\end{array}$ & $\mathrm{pH}_{\mathrm{CaCl} 2}$ \\
\hline $\mathrm{A} / 0-35$ & 1.43 & 5.6 & 1.1 & 160.2 & 130.2 & 5.81 \\
\hline AEs / 35-42 & 1.42 & 4.8 & 0.5 & 95.8 & 102.4 & 5.22 \\
\hline B1s / 42-65 & 1.41 & 4.1 & 0.5 & 101.4 & 101.0 & 4.90 \\
\hline B2g / 65-78 & 1.72 & 4.0 & 0.5 & 122.6 & 99.8 & 4.93 \\
\hline $\mathrm{Cg} / 78-120$ & 1.72 & 3.8 & 0.3 & 138.1 & 96.5 & 4.77 \\
\hline
\end{tabular}


Soil chemical parameters. Due to the differences in common osier plantation soils origin and genesis, it is not sufficient to compare the $\mathrm{pH}$ values and nutrient concentrations. However, it should be noted that $\mathrm{pH}_{\mathrm{CaCl} 2} \mathrm{values}_{\text {in studied }}$ Histosol were higher than ones in studied Arenosols (Table 1-4). In Histosol in the histic horizons up to $40 \mathrm{~cm}$ in depth, where the $\mathrm{pH}_{\mathrm{CaCl} 2}$ values were in the range of 6.01-5.83 (Table 1), roots of common osier are intensively developing. Although, in Arenosols the upper most mineral horizons were of higher $\mathrm{pH}\left(\mathrm{pH}_{\mathrm{CaCl} 2}\right.$ value reaches 6.33) only in the soil in temporarily over moisture humidity fertile site (Site II, Table 3). Further, the mineral horizons in Arenosols in unfertile forest sites were more acidic.

If to compare with Arenosols, accumulation of organic $\mathrm{C}$ have been up to 100 times higher as well as concentrations of total nitrogen about 60 times increased in studied Histosol (Table 1-4). However, the concentrations of mobile $\mathrm{K}_{2} \mathrm{O}$ in Histosol have been either higher till $75 \mathrm{~cm}$ in the depth. Thus, only in Site II, temporarily over moisture humidity fertile forest site have had higher concentrations of organic $\mathrm{C}$, total $\mathrm{N}$ and mobile $\mathrm{P}_{2} \mathrm{O}_{5}$. If to compare with temporarily over moisture humidity unfertile forest site, even in Site I and Stie II, temporarily over moisture humidity fertile forest sites in Arenosol the concentrations of organic $\mathrm{C}$ have been higher by 2.5 times, thus, more than 3 times have been saturated with total nitrogen. Studies on soil chemical parameters have indicated, that higher accumulations of main structural elements in studied soils (organic $\mathrm{C}$ and nitrogen), as well as soil $\mathrm{pH}$ value could be as the factor influencing the higher productivity of common osier.

Productivity of common osier. The productivity of common osier (Salix viminalis L.) plantations have been estimated by regression analysis method. After the evaluation of the fresh biomass weights as well as the volumes in survey plots, the determination coefficient $\left(\mathrm{R}^{2}\right)$ have been estimated. The fresh biomass productivity, have had the tendency to be depending on survey plot soil parameters (Picture 1-2). Thus, the concentrations of organic $\mathrm{C}$ and total $\mathrm{N}$, have had the main influence on the increase in osier productivity in mineral soils (survey plots in Arenosols, Picture 1). It was estimated, that in Arenosols with higher concentrations in soil organic $\mathrm{C}$ and total $\mathrm{N}$ the productivity have been higher by 6 times.

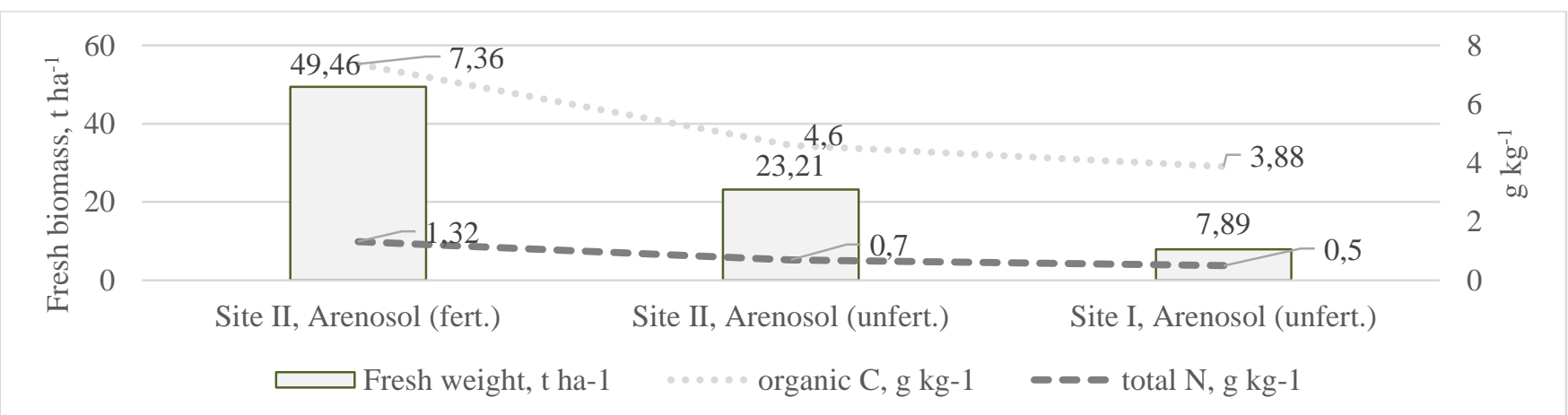

Picture 1. Productivity of common osier (Salix viminalis L.) in studied Arenosols and productivity relation with soil organic carbon and total nitrogen concentrations (numbers: (a) on the columns indicate the productivity of common osier in survey plots, and (b) on the dotted lines indicate the concentrations of soil parameters).

Even though, the concentrations of mobile $\mathrm{P}_{2} \mathrm{O}_{5}$ and $\mathrm{K}_{2} \mathrm{O}$ have been increasing in some of the survey plots, there have been no correlation estimated in relation the changing concentration.

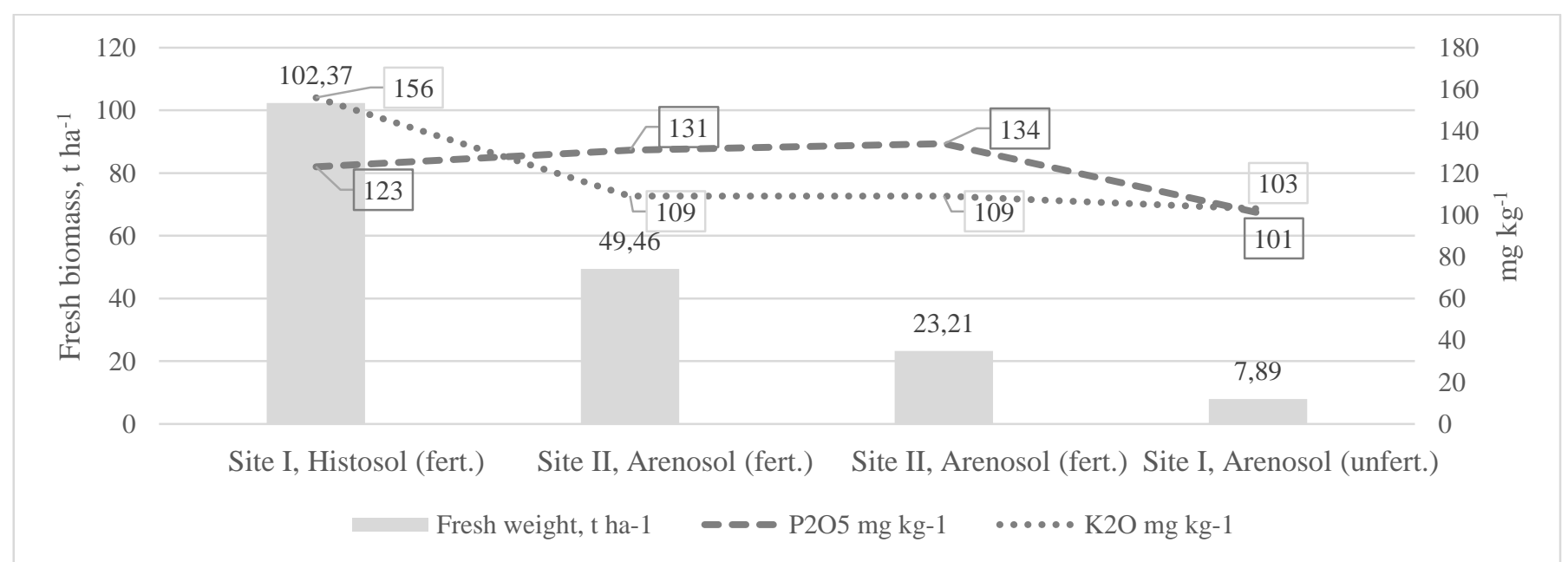

Picture 2. Productivity of common osier (Salix viminalis L.) in Histosol and Arenosols and productivity relation with concentrations of mobile $\mathrm{P}_{2} \mathrm{O}_{5}$ and $\mathrm{K}_{2} \mathrm{O}$ (numbers: (a) on the columns indicate the productivity of common osier in survey plots, and (b) on the dotted lines indicate the concentrations of soil parameters).

According to the data obtained and the theoretical substantiation, the expected productivity of common osier have been planned though the total osier plantations exploitation. It was estimated the most productive plantations of common 
osier in soils with studied parameters could be in 3-6 year rotations. Thus, over the one-year productive plantations, the osier green biomass could reach 63-90 $\mathrm{t} \mathrm{ha}^{-1}$.

\section{CONCLUSIONS}

1. It was estimated that soil in studied survey plots were different. Having done the estimates of chemical parameters as well as indicating the differences in soil structure and composition, four forest sites have been excluded. It was indicated that soil in fertile common osier habitat in Site I could be prescribed as Histosols, soil in unfertile common osier habitat in Site I was prescribed as Arenosol with temporarily over moisture humidity unfertile forest site typology group. Soils in Site II in fertile and unfertile habitats were prescribed as Arenosols but with different forest site typology groups, respectively, temporarily over moisture humidity fertile and temporarily over moisture humidity unfertile forest sites.

2. The Arenosols have had high soil density. It ranged from 1.36 to $1.94 \mathrm{~g} \mathrm{~cm}^{-3}$. The density of organic horizons in Histosol was on average of $0.52 \mathrm{~g} \mathrm{~cm}^{-3}$ and could be indicated as optimal for common osier growth. The $\mathrm{pH}_{\mathrm{CaCl} 2} \mathrm{values}$ in studied Histosol were higher than ones in studied Arenosols. Thus, in Arenosols the upper most mineral horizons were of higher $\mathrm{pH}\left(\mathrm{pH}_{\mathrm{CaCl} 2}\right.$ value reaches 6.33) only in the soil in temporarily over moisture humidity fertile site (Site II). If to compare with Arenosols, accumulation of organic $\mathrm{C}$ and total nitrogen increased in studied Histosol. However, the concentrations of mobile $\mathrm{K}_{2} \mathrm{O}$ in Histosol have been either higher till $75 \mathrm{~cm}$ in the depth. In Arenosols only fertile forest sites have had more concentrations in nutrients.

3. Higher soil $\mathrm{pH}$ value as well as increased concentrations of main structural parameters (organic $\mathrm{C}$ and nitrogen), could be as the factor influencing the higher productivity of common osier. It was estimated, that the weight of green biomass after three years of growth have been higher in Histosol (the productivity of green biomass reached $103 \mathrm{t} \mathrm{ha}^{-1}$ ), thus in studied Arenosols it ranged from $8 \mathrm{t} \mathrm{ha}^{-1}$ to almost $50 \mathrm{t} \mathrm{ha}^{-1}$, respectively, in unfertile and fertile forest sites.

\section{REFERENCES}

1. Bastienè, N., Kirstukas J. 2010. Principles and priorities of riparian buffer strips rehabilitation. Water Management Engineering, Vol. 37, Iss. 57, pp. 71-58.

2. Directive of the European Parliament and of the Council on the promotion of the use of energy from renewable sources. 2009, Brussels, Belgium: European Commission. http://eur-lex.europa.eu, 01.07.2009

3. FAO, 2011. Global Forest Resource Assessment 2010: Main report. FAO Forestry Paper 163, FAO, Rome.

4. Gradeckas, A., Diliūnas, J., Jagminas, E. 2000. The accumulation of microelements and heavy metals in biomass of common osier. Ecology, No. 1, pp. 22-29. (in Lithuanian)

5. Hangs, R. D., Schoenau, J. J., Van Rees, K. C. J., Bélanger, N., Volk, T., Jensen, T. 2014. Examining the nutrient dynamics of willow biomass energy plantations. BioEnergy research, Vol. 7, Iss. 4, pp. 1091-1111. http://dx.doi.org/10.1007/s12155-014-9452-6

6. Kuzovkina, Y., Timothy, A., Volk, A. 2009. The characterization of willow (Salix L.) varieties for use in ecological engineering applications: Co-ordination of structure, function and autecology. Ecological Engineering, Vol. 35, Iss. 8, pp. 1178-1189. http://dx.doi.org/10.1016/j.ecoleng.2009.03.010

7. Jasinskas, A., Liubarskis, V. 2003. Energy-purpose plants and technologies of their usage. Technology, 96 pp. (in Lithuanian)

8. Keoleian, G. A., Volk, T.,A. 2005. Renewable energy from willow biomass crops: Life cycle energy, environmental and economic performance. Critical Reviews in Plant Sciences, Vol. 24, Iss. 5-6, pp. 385-406. http://dx.doi.org/10.1080/07352680500316334

9. Linderson, M. L., Iritz, Z., Lindroth, A., 2007. The effect of water availability on stand-level productivity, transpiration, water use efficiency and radiation use efficiency of field-grown willow clones. Biomass and Bioenergy, Vol. 31, Iss. 7, pp. 460-468. http://dx.doi.org/10.1080/07352680500316334

10. Lygis, V., Matelis, A., Stackevičienè, E., Šimėnas, J., 2006. Establishment, growth and use recommendations for forest plantation. Scientific-practical work report, Vilnius, $70 \mathrm{pp}$.

11. LR - Low of renewable energy resources, 2011, 2011-05-12 (XI-1375), Vilnius. (in Lithuanian)

12. Nassio, Di Nasso N., Guidi W., Ragaglini G., Tozzini C., Bonari E., 2010. Biomass production and energy balance of a twelveyear-old short-rotation coppice poplar stand under different cutting cycles. Global Change Biology and Bioenergy, Vol. 2, Iss. 2, pp. 89-97. http://dx.doi.org/10.1111/j.1757-1707.2010.01043.x

13. Noronha-Sannervik, A. N., Eckersten, H., Verwijst, T., Kowalik, P., Nordh, N. E., 2006. Simulation of willow productivity based on radiation use efficiency, shoot mortality and shoot age. European Journal of Agronomy, Vol. 24, Iss. 2, pp. $156-164$. http://dx.doi.org/10.1016/j.eja.2005.07.007

14. Röhle, H., Skibbe, K., 2012. Ertragsschätzung in Kurzumtriebsplantagen aus Pappel und Weide in Züchtung und Ertragsleistung schnellwachsender Baumarten im Kurzumtrieb ProLoc und Weidenzüchtung: Erkenntnisse aus drei Jahren FastWOOD, ed. Nordwestdeutsche Forstliche Versuchsanstalt, editor. (Göttingen: Universitätsverlag Göttingen; ), pp. 105-116. (In Germany).

15. Stolarski, M., Szczukowski, S., Tworowski, J., Klasa, A., 2008. Productivity of seven clones of willow coppice in annual and quadrennial cutting cycles. Biomass Bioenergy, Vol. 32, Iss. 12, pp. 1227-1234. http://dx.doi.org/10.1016/j.biombioe.2008.02.023

16. Wael, A., 2009. Modelling of biomass production potential of poplar in short rotation plantations on agricultural lands of Saxony, Germany. Technische universitat Dresden. 